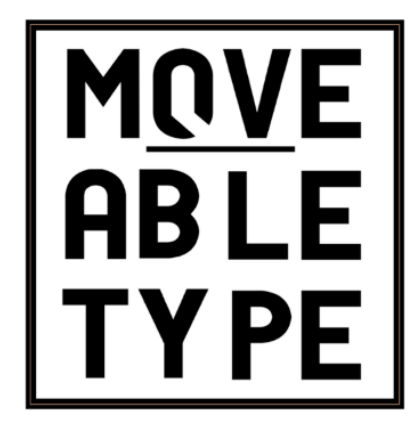

Article: 'another part rotten, another gnawed by rats...': Tidying Up the Conway Papers

Author[s]: Daniel Starza-Smith

Source: MoveableType, Vol. 5, 'Mess' (2009)

DOI: $10.14324 / 111.1755-4527.045$

MoveableType is a Graduate, Peer-Reviewed Journal based in the Department of English at UCL.

(C) 2009 Daniel Starza-Smith. This is an Open Access article distributed under the terms of the Creative Commons Attribution License (CC-BY) 4.0https://creativecommons.org/licenses/by/4.0/, which permits unrestricted use, distribution, and reproduction in any medium, provided the original author and source are credited.

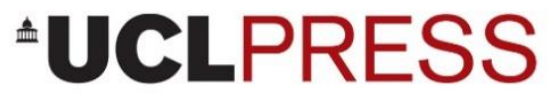




\section{'...another part rotten, another gnawed by rats...': tidying up the Conway Papers}

I am researching an archive that is both too messy and not messy enough. Poetry and drama by John Donne, Ben Jonson and many other early modern authors, can be found in a large and disparate manuscript collection now known as the Conway Papers. But what are these manuscripts doing here, and why are they all mixed up? What kinds of documents are they, and what can the bibliographical and historical context of the Conway Papers tell us about their composition, circulation and reception? In order to assess the collection, I will introduce its original owners and delineate the provenance of the papers, before turning to a selection of the literary manuscripts as a case study to reveal some of the archive's potentials for research. My article is partly inspired by an article that appeared in an earlier edition of this journal, Helen Freshwater's 'The Allure of the Archive'. Freshwater demonstrates how 'the archive's traditional legitimacy' has been replaced with 'a site of conflicted signification'. 'Drawing on Derridean and Foulcauldian theory, Freshwater proposes using semantically less rigid approaches to the analysis of the 'statements' (Foucault's word) inherent in any archive. My approach is based on the methodologies of new historicism and cultural materialism: this paper will reappraise the ontological status of the Conway Papers what the archive is - by attempting to recover the original social conditions that created it. The only way I can answer these questions, and attempt to tidy up the Conway Papers, is to accept the archive's inherent messiness, to negotiate with a false tidiness imposed by the original archivists, and to discern an acceptable category of mess.

Sir John Conway (1535-1603), was a respected Elizabethan soldier who served under Robert Dudley, first Earl of Leicester in the Netherlands, and was knighted in 1559 on the accession of Queen Elizabeth. He was the author of a devotional tract entitled Meditations and Praiers (first edition 1569), which passed through six editions, and was eventually retitled as Poesie of Floured Praiers (1611). The work was originally composed while Sir John was imprisoned for suspected treason against the queen, and partly served as a plea for clemency. Sir John Conway unwittingly began a tradition of literariness that the family maintained for several generations; his son and grandson, both called Edward, while apparently not authors themselves, were important collectors of literature and patrons of poets. ${ }^{2}$

The grandson, Edward, the second Viscount Conway (1594-1655), was one of the most important book collectors of the seventeenth century: the books from his London and Irish libraries number around 13,000 when combined, and cover topics as diverse as religious controversy and stain removal - though his overriding passion for literature is clear. ${ }^{3}$ Known to the Earl of Clarendon as 'a voluptuous man in eating and 
drinking', whose breeches were widened each year to accommodate his growing girth, he was a less-than-effective officer in the navy and cavalry, remaining loyal to the crown during the Civil War until his books were impounded as a punishment. ${ }^{4}$ This Conway associated with the younger John Donne, and with Sir Walter Ralegh's son Carew, two of the many agents who sent him luxury items such as food, clothing and literary manuscripts. His somewhat bawdy Cavalier taste can be illustrated by this ditty, found among the manuscripts of the Conway Papers:

The London lasses are soe sto'ute they care not what they doe they will not lett you hau'e abou'te vnder a crown'e or twoe They dawbe theire chops \& curle their lockes their breathes perfu'me they doe their tayles are pepperd with a pox $\&$ that you' are welcome too

Then giu'e mee the country bucksome lasse hott pipeing from the cowe Shall take a tou'ch vppon the grasse I merry \& thanke you' too her colours as fresh as roose in Ju'ne her Skin' as Soft as Silke Sheele doe her busines to Some tu'ne and freely spend her milke.

This anonymously transcribed ballad bears an embarrassed covering note: 'Pray my Lord tell nobody from whom this song comes, for I am ashamed to owne it'. 'While amusing in itself, the aside bears testimony to some of the problems inherent in the collection, where manuscripts are frequently undated and lacking in authorial ascription.

In contrast to his pleasure-seeking son, the first Viscount Conway (d.1631) was considered a rather wearisome civil servant by some of his contemporaries. Conway was knighted in 1596 by Robert Devereux, the second Earl of Essex and Elizabeth's favourite. On Essex's recommendation, Conway was appointed Lieutenant-Governor of the Brill, one of the Cautionary Towns in the Netherlands. There he was stabbed by 'a madman', leading to lifelong illness. ${ }^{6}$ In later life, he acted as Secretary of State to both James I and Charles I, but many courtiers believed Conway had reached his position by playing the patronage system, being particularly obsequious to the allpowerful favourite George Villiers, Duke of Buckingham, rather than by demonstrating his administrative competency. Writing of Conway's appointment, John Chamblerlain noted that King James had commended Conway's 
birth, soldiership, knowledge of languages, sufficiency, and honesty; others add his courtiership in trying to fasten the title of Excellency on [Buckingham]. ${ }^{7}$

Whatever his route to power, the significance of Conway's position at Court should not be underestimated. As Secretary, Conway received information about virtually every major event in the country, and frequently beyond, within a few days of its occurrence. As a member of the Privy Council (and later its president), he was also instrumental in the everyday management of royal policy and state government. Conway employed his own spies abroad, received regular manuscript newsletters from agents in Europe detailing events on the continent, and played an important part in the licensing of the press. He was thus in a position of privileged intelligence and at the centre of a number of networks in which written materials were circulated.

Having run away from school as a child to join the army, Conway had no formal education and appalling handwriting. ${ }^{8}$ Nevertheless, these limitations did not preclude his interest in literature. It was probably in the Low Countries that Conway developed an interest in culture as a means of progressing his career. There is significant evidence to suggest the family's links to the era's most celebrated literary courtier, Sir Philip Sidney. During his time of service in the Netherlands, for example, Conway associated directly with Sir Fulke Greville and Sir Robert Sidney, Sir Philip's best friend and brother respectively; Sir Fulke was also Conway's cousin. The potential Sidney link is important in analysing Conway's career: Roy Strong has argued for a mantle of 'Protestant military chivalry' that had been worn in turn by Sir Philip Sidney, the Earl of Essex and King James's son Prince Henry (the heir to the throne), and the pattern of Conway's search for patronage matches this theory neatly. ${ }^{9}$ Conway had been knighted by Essex and wrote to him directly on several occasions seeking preferment. Having gained access to the court of Prince Henry, Conway fought at Barriers with him in 1610 and 1611, and attempted to recruit the Dutch artist, Michiel van Mierevelt, to be the young royal's official painter. No doubt a polished courtly sheen assisted Conway in his attempts to impress powerful potential patrons: a 1610 inventory of Conway's Warwickshire library records 213 books, including Ben Jonson's Sejanus, and he is known to have owned several musical instruments. ${ }^{10}$ However, after Prince Henry died in 1612 at the age of 18, Conway made a pragmatic move and cultivated George Villiers, who within the decade would become the allpowerful Duke of Buckingham and James's unrivalled favourite. Under Buckingham's patronage, Conway was appointed Secretary of State in 1622, and it is in this role that his collection of letters and documents grew exponentially.

The Conway Papers were rescued from obscurity by Horace Walpole, fourth Earl of Orford, in the eighteenth century when he visited Ragley Hall in Warwickshire, by then the seat of Henry Seymour Conway, Marquess of Hertford. In addition to thousands of formal documents, the collection contains poems and drama by John and 
Francis Beaumont, Thomas Middleton, Sir Henry Wotton, Henry King, Thomas Carew, Lady Mary Wroth, William Herbert, third Earl of Pembroke, and much anonymous political and occasional verse and drama. The most interesting items, from my perspective, are one poem and three masques by Jonson, and thirteen poems by Donne. Poems by Donne's closest friend, Sir Henry Goodere, plus numerous others in Goodere's hand are particularly noteworthy, as we know Donne regularly sent Goodere his work, and that Goodere was also friends with Jonson, and a Warwickshire neighbour of Conway's. Walpole's breathless account of his discovery usefully summarises some of the collection's principal attributes:

Think what I have in part recovered! Only the state papers, private letters, etc., etc., of the two lords Conway, Secretaries of State. ${ }^{11}$ How you will rejoice and how you will grieve! - They seem to have laid up every scrap of paper they ever had, from the middle of Queen Elizabeth's reign to the middle of Charles the Second's. By the accounts of the family there were whole rooms full, all which ... were by the ignorance of a steward consigned to the oven and to the uses of the house. What remained, except one box that was kept till almost rotten in a cupboard, were thrown loose into the lumber-room, where, spread on the pavements, they supported old marbles and screens and boxes. From thence I have dragged all I could, and have literally, taking all together, brought away a chest near five feet long, three wide and two deep, brim full. Half are bills, another part rotten, another gnawed by rats, yet I have already found enough to repay my trouble and curiosity, not enough to satisfy it ... ${ }^{12}$

Walpole claims he retrieved a single chest of papers from a collection that once occupied several rooms. The thousands of Conway Papers manuscripts available to us therefore constitute a small and damaged portion of this archive, which could have survived in a much less messy state than it has done. The remaining fragments of the family's collection are now scattered through several repositories, and many survive in poor physical condition. The challenge is to draw as much evidence as possible from what remains.

The technical difficulties involved in such an undertaking are manifold. John Wilson Croker, the man who sorted through the manuscripts and returned them to the Home Secretary as strayed state papers, stamped them as 'Conway Papers'. However, I have identified material without the stamp that almost certainly derives from the family papers - for example, bawdy letters from the younger John Donne to the second Viscount (now held in Warwickshire Record Office and at University College London). ${ }^{13}$ One significant grouping in the National Archives, a volume of seventeenth-century manuscripts compiled in the nineteenth century (SP 9/51), lacks a stamp but presents numerous significant overlaps with official Conway Papers documents, and there is a strong argument that it should be counted among them. ${ }^{14}$ Manuscripts now presumed missing include documents that Walpole gave to his friends as gifts, some confiscated by Charles I on the first Viscount's death, and others 
that were simply misplaced. Among approximately 60 volumes-worth of unbound papers that were recovered, a great many were subject to damp, mistreatment, or the appetites of Ragley Hall's rodents and were thus too deteriorated to save. Even among what can be identified for certain, much of the poetry has been separated from the covering sheets or letters in which it was delivered, and as a result most manuscripts lack indications of both author and date.

When Croker bequeathed the collection to the nation, the manuscripts were split roughly into public and private documents between the Public Record Office (now the National Archives) and the British Museum (now the British Library). However, there are some non-literary Conway documents in the British Library as well as significant poems in the Conway Papers at Kew. Within the National Archives the Conway Papers have been shuffled chronologically into the collections rather than preserved as an independent cache, making them harder to study en masse; while this is an understandable approach to the ordering of state papers, it is unfortunate that they were never catalogued separately. It is unclear therefore whether we should categorise the Conway Papers as a cohesive collection with some kind of unity of purpose, or a semi-random assortment of 'every scrap of paper [the family] ever had'. As James Knowles correctly observes, the 'complex redistribution frustrates any detailed reconstruction of the original context. ${ }^{15}$

Despite these complications, there is, paradoxically, a danger of defining the Conway Papers as a neater unit than they actually are. Many of the most eye-catching literary manuscripts were collected in the nineteenth century into a large bound volume of 170 folios, featuring about 125 poems, ballads, ditties and masques (British Library Add. MS 23,229, or B11). This volume, the so-called Conway Manuscript, can give the impression that the Conway Papers poems were so gathered in the seventeenth century. In fact, there is no evidence for this and the poems may have been as carelessly treated by their original owners as they were by the ignorant steward whom Walpole encountered. B11 is not a poetical miscellany, one of the volumes into which an intellectually-inclined man (or sometimes woman) would transcribe selections from their favourite authors; rather, it is a collection of miscellaneous manuscript separates and fascicles (small gatherings). These are important considerations, as many of the authors included in the volume can be connected to one another biographically. In addition, a great many Courtly characters are mentioned by name, suggesting intriguing links between the manuscripts, and between the manuscripts and their owners. These hints of alternative provenances can be misleading.

One item in B11 sounds an important warning note: the sonnet 'Love and Jealousy' (fol. 45r-v) was written by Henry Carey, who was born in 1687, thirty-two years after the second Viscount died. It is now stored alongside John Donne poems that very likely entered the Conway collection in the 1610 s. Other than their current location, then, these examples have almost nothing in common. A fragment of Donne's Satires $I V$ and $V(B 11$, fols. 95r-98r) is another case in point: the manuscript consists of four 
folios that were clearly once bound into a larger gathering, in a highly attractive calligraphic scribal hand. It may seem at first that this document relates to the other Donne poems here, and in an ordered collection we might expect them to share characteristics. In fact, judging by the handwriting and paper evidence, these folios are almost certainly related to the so-called Leconfield manuscript from the collection of Henry Percy, ninth Earl of Northumberland. Bibliographically, the manuscript offers no evidence at all of a relationship with the other Conway Donne material.

In order to evaluate this collection without prejudice, therefore, one must refragment it, analysing each manuscript on its own internal evidence before presuming to make links with other items.

A key consideration in the analysis of Donne's early poetry is the nature of manuscript circulation in the seventeenth century. While print was by this time an established method of publication, it was by no means entirely the dominant or preferred one, as Arthur Marotti, Peter Beal, Henry Woudhuysen and others have demonstrated convincingly in recent years. As Harold Love argues, 'scribal transmission [of a text] might be chosen without any sense of its being inferior or incomplete'. ${ }^{16}$ Indeed, there were distinct advantages to the medium, as Woudhuysen explains:

A professional scribe might be able to make a more beautiful volume, but an author's own hand had something of his essential character in it. In the complex business of presenting a manuscript book as a gift to a potential or actual patron, the more individual, the more direct the transaction could be made, the better. ${ }^{17}$

Even if a manuscript was not in the original author's hand, as a handwritten artefact it was nevertheless imbued with a unique intimacy.

In an age when the notion of individual authorship was not stable or rigid, the significance and mechanics of the text's publication and social transactions become highly rewarding fields for investigation. ${ }^{18}$ Furthermore, reading literature in a context like that provided by the Conway Papers demands an awareness of the social context of the original reader, and of the processes of circulation that formed his or her reading experience. As Roger Chartier puts it, "no text exists outside of the support that enables it to be read; any comprehension of a writing ... depends on the forms in which it reaches its reader'. ${ }^{19}$ This is doubly true of the Conway Papers, in which we must be aware of our own reading situation while attempting to recover the original contexts. With the above considerations in mind, I offer below a case study of a small selection of the Conway Papers, those in the hand of Donne's friend Sir Henry Goodere, which pose questions about the role of literature in early modern patronage relationships. We think of Donne as a coterie poet, sharing his manuscripts with a 
close circle of friends; Goodere was perhaps the most frequent recipient of Donne's verse in this manner. But Goodere did not keep this poetry to himself - he circulated it along with other material to potential patrons like Conway. I want to argue that as the poems passed from writer to reader, from giver to receiver, the ontological status of the documents being read was altered - and, in fact, that the very nature of manuscript publication allows for precisely this kind of flexibility.

After Donne wrote his poems he sent autograph copies to Goodere, an intimate, personal, coterie transaction signifying friendship, trust and common values. Goodere then made copies of these poems in his own handwriting and sent them on to his Warwickshire neighbour Conway, then an ambitious soldier initiating himself into Courtly circles. By circulating Donne's verse in this way, Goodere may have been helping his friend - whose notoriously ill-judged marriage had made him practically unemployable - by introducing him to a potential dispenser of patronage and demonstrating the poet's mental ingenuity and professional potential. Goodere had form in this matter, as the prime mover of Donne's search for patronage, introducing him to influential men and women like Lucy, Countess of Bedford. Alternatively, Goodere was using Donne's works to raise his own stock, giving poetical manuscripts as gifts that would encourage Conway to act as his patron and protector. On balance, the latter explanation seems more likely: Goodere's finances were steadily drained by his life at Court (he even contemplated marrying a rich widow in 1614), and it was, in fact, to Conway that Goodere turned for help in 1626 and 1627. Goodere wrote to Conway, asking him to persude Buckingham to petition the King. By scaling this ladder of patronage, Goodere won temporary immunity from his creditors, although he remained afflicted by debt for the rest of his life.

It seems very likely that Goodere gave Conway poetical manuscripts as a form of 'payment' for these kinds of favours, cultivating him as a patron from around 1610. The giving of gifts to potential patrons in early modern European cultures did not operate in a linear fashion like a financial transaction, although economic metaphors are not entirely inappropriate. ${ }^{20}$ Rather, gift exchange created a bond of obligation between giver and receiver: as Mervyn James explains, 'the gift necessarily entails the notion of credit'. ${ }^{21}$ However, the essential nature of such transactions had altered fundamentally with the spread and development of humanist discourse, as Lorna Hutson has argued persuasively in The Usurer's Daughter. One of Hutson's central theses is that 'humanism relocates the instrumentality of male friendship, translating it from alliance and gift-exchange to persuasive communication. ${ }^{22}$ As evidence, she quotes Erasmus's letter to his editor, Peter Gilles:

Friends of the commonplace and homespun sort, my open-hearted Pieter, have their idea of relationship [...] attached to material things; and if they ever have to face a separation, they favour a frequent exchange of rings, knives, caps and other tokens of the kind [...] But you and I, whose idea of friendship rests wholly in a meeting of minds and the enjoyment of studies in common, might well greet one 
another from time to time with presents for the mind and keepsakes of a literary description. $^{23}$

Erasmus contrasts a material, external display of friendship against the establishment of an internal, mental union based on shared thoughts and values. Crucially, his conception of friendship does not preclude gift exchange; rather, it insists that the object given should be a physical expression of an intellectual bond. It is telling that Erasmus should mention 'keepsakes of a literary description' because the gift of a manuscript poem conveniently borders the two ideas he opposes. As a physical transaction of property it establishes a bond of obligation and fealty in the traditional manner, but as a transmitter of thoughts, desires, opinions and news, it also represents an intellectual interaction that subtly allies giver and receiver within a privileged network of communication. For a client writing to a patron, the exchange of verse allowed the economies of the patronage system to operate discretely in the rhetorical garb of Erasmian amity. While Donne and Goodere embraced the economy of obligation as a means of encoding their relationship, Goodere's subsequent interactions with Conway bring the metaphor of the market to life. As Donne's manuscript poems passed through Goodere's ownership they were transformed from tokens of friendship from Donne to Goodere, into implicit requests for favour from Goodere to a social superior, and a down-payment for this favour.

Conway seems to have acknowledged the poetry as appropriate repayment, given his later support of Goodere. But this does not explain why Conway might have thought of literature as something of value. In fact, Conway appears to have been reading these poems with his own specific agenda, which again alters the manuscripts' ontological status. James Knowles has investigated Conway's ownership of Ben Jonson's masque The Entertainment at the Opening of Britain's Burse (SP14/44/62*); this manuscript is one of several Jonson works in the Conway archive, another of which, $A n$ Entertainment of the King and Queen at Theobalds (SP 9/51/41-2), is in Goodere's hand. ${ }^{24}$ Knowles argues that Conway's acquisition of the Burse was an act of political intelligence-gathering, or to change his formulation slightly, cultural autodidacticism: Conway was reading Jonson's dramatic work in order to brush up on his knowledge of current affairs. The same can be argued of the poems in Goodere's hand: one that he gave Conway was a copy of Donne's epithalamion on the 1613 marriage of Robert Carr, Earl of Somerset, then James I's chief favourite (B11, fols. 10r-14v). Knowledge of this marriage and the cultural events surrounding it would have given Conway access to invaluable information about life at court, and the means to impress highranking courtiers. Other Conway Papers material tends to corroborate this view: the anonymous 'Running Masque' (B11, fols. 3r-8r), for example, performed by thirteen important courtiers, including Buckingham, or the two other Court masques by Jonson (Theobalds, as above, and extracts from the Masque of Gipsies Metamorphosed, SP 14/122/58). There are two poems memorialising Prince Charles's voyages to Spain to negotiate his marriage (SP 14/153/12-12X and SP 14/153/112), an elegy on the death of Prince Henry (in duplicate, SP 14/71/49B and B11, fol. 133r-v) and half a dozen 
poems on the death of Conway's patron Buckingham. The fact that a great many of the first Viscount's contemporaries are named in the Conway Manuscript alone is further evidence that Conway was at least partly using poetry to gather intelligence about his society.

Reading Donne in the Conway Papers reveals insights into the early contexts of his readership. He emerges as a very different kind of poet to the scrupulously-edited writer we tend to encounter today. As Love says, "Any attempt to enter that first reading experience must always take account of the company poems were accustomed to keep'. ${ }^{25}$ In the Conway Papers - reconstituted to their messiest state - we see Donne's work lying alongside rude ditties and official letters; neat presentation transcripts of poems next to rough, scrawled versions; paper from the mid sixteenth century mixed up with paper from the late seventeenth century. The messy nature of the archive calls urgent attention to the physical state of the texts themselves. To investigate properly the literary works within we must be aware of 'the entire sociohistory of the work - from its originary moments of production through all its subsequent reproductive adventures', ${ }^{26}$ and we must edit the manuscripts 'in sociocentric rather than in author-centric ways' ${ }^{27}$

The result of this approach is a blurring of authorial identity, as Marotti explains:

'Donne' as an author would appear to be less an idealized font of creative originality and more an historically-evolving, socially-produced literary identity, the result of 'corrupt' as well as 'authoritative,' spurious and dubious as well as authenticated, texts, original social contexts as well as successive historical acts of recontextualization. ${ }^{28}$

As the editors of the Donne Variorum project have repeatedly demonstrated, modern notions of Donne's corpus have been created by a cumulative process of selective editing, with choices of textual variants taken from hundreds of different manuscript witnesses. Each witness is the product not only of a solitary literary genius, but of the publication method with which he chose to circulate his works, and the unique social history each manuscript developed. Manuscript publication emerges from this analysis as a peculiarly flexible form of communication, almost Montaignian in its ability to adapt to circumstance, "not only by chance but also by intention. ${ }^{29}$ Many Conway Papers poems seem inherently designed to encompass a metamorphic ontology; there is an acknowledgment that their text is unstable, that it will be appropriated, excerpted, copied and passed on. Richard Wollman has complained that Marotti, in his work on Donne's coterie writing, 'jettisons Donne the author in order to show ... Donne the author-function', and he is right that it can sound cynical and unfeeling to read literature in this way. Nevertheless, when we read poems by Donne and Jonson in the 
Conway Papers we are forced to consider the work these manuscripts performed, to see them as functional as well as aesthetic objects. But we can only start to adjust to this process once we have made the right kind of mess of the archive.

DANIEL STARZA-SMITH

Daniel Starza-Smith is a graduate student at University College London, funded by the AHRC, researching the circulation of John Donne's early verse in manuscript, particularly in the context of the Conway Papers.

\footnotetext{
${ }^{1}$ Helen Freshwater, 'The Allure of the Archive: Performance and Censorship', Moveable Type, 4 (2008), http://www.ucl.ac.uk/english/graduate/issue/3/pdf/freshwater.pdf [accessed 1 December 2009] 5-24 (p. 16).

${ }^{2}$ Edward, first Viscount Conway is known to have translated poetry from Spanish (British Library Add. MS. 23,229, fols. 74r-75r), and the second Viscount published an eight-page account of military activity in Ireland, A relation from the Right Honourable the Lord Viscount Convvay, of the proceedings of the English Army in Ulster (1642). Add. MS 23,299 is known as B11 to the editors of the Donne Variorum, and is cited as such henceforth.

${ }^{3}$ His libraries have been examined most fully in H. R. Plomer, 'A cavalier's library', The Library, n s., 5 (1904), 158-72, and Ian Roy, 'The Libraries of Edward, 2nd Viscount Conway, and Others: an Inventory and Valuation of 1643', Bulletin of the Institute of Historical Research, 41 (1968), 35-46. These articles refer, respectively, to Library Catalogue of Edward, 2nd Viscount Conway in the Armagh Robinson Library, and National Archives SP 20/7.

${ }^{4}$ W. Dunn Macray (ed.), Clarendon's History of the Rebellion and Civil Wars in England, 6 vols (Oxford: The Clarendon Press, 1888), 2.82.

${ }^{5}$ B11, fols. 43r-v. For more on the second Viscount's patronage of wits, see Tim Raylor, Cavaliers, Clubs, and Literary Culture (London: Associated University Presses, 1994), passim.

${ }^{6}$ Conway had been suffering an ague at the time. According to Sir John Oglander, 'the madman ran my Lord Conway through the body, which present put away his ague. But the remedy was worse than the disease.' A Royalist's Notebook, ed. by Francis Bamford (London: Constable \& Co., 1936), p. 145. ${ }^{7}$ Calendar of State Papers Domestic, James I, vol. 147, item 27; John Chamberlain to Sir Dudley Carleton; 12 October 1623.

${ }^{8}$ Indeed, a document supposedly written by him was once spotted as a forgery for being too legible. 'There has been a proffer to print a certain book in folio of English verses in commendation, as is pretended, of the late Duke [of Buckingham, assassinated in 1628]. The pretenders affirmed they had leave under Conway's hand. [William] Laud desired to see it, because the King's charge was strict that no papers concerning the Duke should be suddenly printed. The papers were brought by one who calls himself Mr. Darcie, and goes for the man that puts it to the press. There he saw the Secretary's hand, but so fairly written that after the party was gone it drew him into some jealousy.' Calendar of State Papers Domestic, Charles I, vol. 118, item 32; Laud to Secretary Conway; 7 October 1628.

${ }^{9}$ Roy Strong, Henry, Prince of Wales and England's Lost Renaissance (London: Thames and Hudson, 1986), passim, e.g. p. 14.

${ }^{10} \mathrm{SP} 14 / 58 / 48 \mathrm{~A}$ is a 1610 inventory mentioning five lutes, two olpherey, and one base violl; a similar document, SP 14/72/132, lists one cittern and five lutes. The book collection is inventoried at SP14/57/114B.

${ }^{11}$ The other Secretary of State to whom Walpole refers was Edward, first Earl Conway, son of the second Viscount. The Conway Papers comprise his documents, too, although this area is outside the scope of my study.

${ }^{12}$ Horace Walpole to George Montagu, 20 August 1758. Quoted in Marjorie Hope Nicolson, Conway Letters, rev. by Sarah Hutton (Oxford: The Clarendon Press, 1992), p. xxiv.

${ }^{13}$ Warwickshire Record Office CR114A/793, and University College London Ogden MS 31.

${ }^{14}$ Peter Beal is open to the possibility; Gabriel Heaton is more skeptical. Peter Beal, Index of English Literary Manuscripts, 4 vols (London, 1980), 1.i.248, and Gabriel Heaton, 'Performing Gifts: The Manuscript Circulation of Elizabethan and Early Stuart Courtly Entertainments' (unpublished doctoral thesis, Cambridge University, 2003), pp. 119-20.

${ }^{15}$ James Knowles, 'Jonson's Entertainment at Britain's Burse', in Re-Presenting Ben Jonson, ed. by Martin Butler (Basingstoke and London: MacMillan, 1999), pp. 114-51, at p. 118.
} 


\footnotetext{
${ }^{16}$ Harold Love, The Culture and Commerce of Texts (Amherst, MA: University of Massachusetts Press, 1993), p. 35.

${ }^{17}$ Henry Woudhuysen, Sir Philip Sidney and the Circulation of Manuscripts, 1559-1640 (Oxford: The Clarendon Press, 1996), p. 103.

18 ' $[\mathrm{I}] \mathrm{t}$ may matter to modern readers and editors whether a poem is or is not by Donne or Jonson, but their contemporaries appeared to care little $[\ldots]$ the very concept of individual authorship in the Renaissance was a relative one'. Ibid., p. 9 and p. 162.

${ }^{19}$ Roger Chartier, 'Texts, Printing, Reading', in The New Cultural History, ed. by Lynn Hunt (Berkeley, CA: University of California Press, 1989), p. 161.

${ }^{20}$ Jason Scott-Warren, Sir John Harington and the Book as Gift (Oxford: Oxford University Press, 2001), passim.

${ }^{21}$ Marcel Mauss, The Gift: The Form and Reason for Exchange in Archaic Societies, trans. W. D. Halls (London, 1990), p. 36.

${ }^{22}$ Lorna Hutson, The Usurer's Daughter: Male Friendship and Fiction of Women in Sixteenth Century England (London: Routledge, 1994), p. 11.

${ }^{23}$ Desiderus Erasmus, Parabolae sive Similia, trans. R. A. B. Mynors, in The Collected Works of Erasmus, ed. by Craig R. Thompson (Toronto: University of Toronto Press, 1978) 23.131. Quoted in Hutson, p. 4.

${ }^{24}$ The Burse was the New Exchange, a shopping centre for exotic goods opened in 1609 by Robert Cecil, first Earl of Salisbury.

${ }^{25}$ Love, p. 6

${ }^{26}$ Jerome McGann, 'Theory of Texts', LRB, 18 February 1988, p. 21.

${ }^{27}$ Arthur Marotti, 'Manuscript, Print, and the English Renaissance Lyric', in New Ways of Looking at Old Texts, ed. by W. Speed Hill (New York, NY: Renaissance English Text Society, 1993), p. 211. ${ }^{28}$ Ibid., p. 215.

${ }^{29}$ Michel de Montaigne, 'On Repentance', Essays, trans. J. M. Cohen (Harmondsworth: Penguin, 1958), p. 235.
} 